\title{
Hollow Hopes, Flypaper, and Metaphors
}

Malcolm M. Feeley

Gerald N. Rosenberg, The Hollow Hope: Can Courts Bring About Social Change? Chicago: University of Chicago Press, 1991. Pp. xii +425. $\$ 29.95$.

This is a good book, a fine book. It joins the ranks of three other outstanding books that have systemically explored the role of courts in effecting social change, Donald Horowitz's Courts and Social Policy, Joel Handler's Social Movements and the Legal System, and Stuart Scheingold's The Politics of Rights. ${ }^{1}$ This is a good company. Indeed, the book builds on the strengths and insights of each of these earlier volumes and, as a consequence, is both more tightly organized and systematic than they are. But the book is also wrong. It fails to make its central arguments convincingly, and it wholly fails to address the central problematics it reveals. In this essay I shall try to explain why at the same time Rosenberg's book is both important and wrong.

\section{THE SIGNIFICANCE OF THE HOLLOW HOPE}

To his credit, Rosenberg states his thesis boldly and runs with it headon. His thesis is that the courts are not and have not been engines of

Malcolm M. Feeley is professor, School of Law, University of California, Berkeley. For the current year he is Director of the University of California Study Center at Hebrew University in Jerusalem.

1. Donald L. Horowitz, The Courts and Social Policy (Washington, D.C.: Brookings Institution, 1977); Joel Handler, Social Movements and the Legal System (New York: Academic Press, 1978); and Stuart Scheingold, The Politics of Rights (New Haven, Conn.: Yale University Press, 1974). 
social change in the United States. He purports to demonstrate this by examining the impact of landmark Supreme Court decisions during the most activist phase in its history, the era of the Warren Court. In so doing he develops two models of courts, a "dynamic court" model, which postulates a powerful court that has been instrumental in effecting significant social change, and a "constrained court" model, which holds that courts face a near-insuperable set of constraints and conditions that make it next to impossible for them to effect significant social change. ${ }^{2}$

Most of the book is conceptually cast in the form of a quasi-experiment, in which Rosenberg tests these two models by examining social policies and practices before and after a number of Supreme Court decisions often regarded as important sources of new policies. His conclusion in each of these inquiries is that the Court's decision has had no or virtually no significant independent direct or indirect effect. When change has occurred, he argues, it has been due to other factors, most notably political efforts wholly separate from the courts.

On one level the book is enormously successful. By systematically framing issues, by separating normative from empirical questions, by focusing on the issue of capacity, by insisting on quantitative indicators of impact, and by revealing the mushy-headed romanticism of many proponents of a "dynamic" court, he appears to have developed a compelling case for his argument. Indeed, contrary to a number of other reviewers who have complained about his data collection and analysis, I am largely convinced by it.

What, then, is the problem with the book? It is that at heart Rosenberg remains a lawyer and that he has written a brief rather than a theoretically informed social science study. ${ }^{3}$ His book unfolds like a legal argument, and as such it contains all the strengths and weaknesses of this form of analysis. On the plus side, Rosenberg states his central thesis clearly, has a rambunctious adversarial style, writes with clarity, and insists on documented evidence. In all this, Rosenberg succeeds in shifting the burden of proof to those who claim great powers for the courts. By challenging the pantheon of big ones-Brown v. Board, Roe v. Wade, Mapp v. Ohio, Miranda ข. Arizona, and Baker v. Carr, ${ }^{4}$ and their progeny-as more myth than substance and by offering copious and systematically presented evidence supporting his claims, no one can any longer point to these cases

2. In "Reform Litigation on Trial," in this symposium, Michael McCann describes and discusses these two models at some length, so I shall not repeat that description here.

3. In his preface Rosenberg gives a brief autobiography. He notes that as a youngster growing up in a liberal New York City family, he had great respect and expectations for the federal courts, and only sometime later came to question their efficacy.

4. Brown v. Board of Education, 347 U.S. 483 (1954); Roe v. Wade, 410 U.S. 113 (1973); Mapp v. Ohio, 367 U.S. 643 (1961); Miranda v. Arizona, 377 U.S. 201 (1966); Baker v. Carr, 369 U.S. 186 (1962). 
as "obvious" examples of the efficacy of litigation. It is now incumbent on those who believe that courts can and do effect significant social change to marshal evidence to support their claims. This is a significant accomplishment. Rosenberg has challenged conventional wisdom, and won.

Another strength of the book is that Rosenberg has been inclusive and creative in his search for indicators of impact. ${ }^{5}$ One may not agree that he has always used the right measures, ${ }^{6}$ but one must respect the herculean effort. And Rosenberg is immensely successful in engaging the reader in his enterprise. After two or three indicators of impact are presented, skeptical readers (which include nearly all my law students in a recent seminar in which I used the book) are likely to ask, "OK, but what about ... ?" But just as the question is about to be asked, Rosenberg anticipates it and answers it himself. In short, he presents a powerful brief against the argument that the courts are and have been major forces for significant social change.

Despite these many strengths, the book suffers from a pervasive reliance on lawyers' rhetorical formulations rather than social science analysis to frame and develop its central concerns. In making these assertions I recognize that I am dangerously close to criticizing Rosenberg for not writing the book I would like him to have written. But I think I can avoid this charge when I show that he fails to explore adequately the central concepts that he himself presents. This is seen most notably in his failure to explore the implications of his two central metaphors, the "hollow hope" and "flypaper court." Below I discuss these concerns and outline two ways he might have developed his analysis more fully.

\section{THE HOLLOW HOPE}

Rosenberg is most successful in the quintessential lawyer's task of demolishing someone else's arguments, those whose hopes he argues are "hollow." More particularly he succeeds in showing that the proponents of the dynamic court have made sloppy assertions that cannot be sustained by available evidence. These proponents are primarily liberal apologists who celebrate the social policies of the Warren and Burger Courts, and who believe that the "dynamic" Court has effected significant social poli-

5. This is not quite right. His two central concerns-civil rights of African Americans and abortion/women's rights-are expansive treatments. His third catch-all section on environment, reapportionment, and criminal law is skimpy and not always carefully considered.

6. For instance, in measuring the before/after impact of Roe v. Wade, he relies on nationwide estimates on numbers of abortions. Almost everyone who has reflected on the impact of Roe acknowledges that it is likely to have had differential impacts in different states, depending on local cultures and the expansiveness of abortion laws prior to Roe. Nationwide figures are likely to obscure variable impact within states. 
cies through its landmark decisions. But they also include conservatives who believe that the Court has effected significant social change but lament the fact. ${ }^{7}$ In sharp contrast to both these variants, Rosenberg argues that the Court has had little if any impact on major social policies.

Despite the impressive evidence Rosenberg marshals to support his views, he has not disposed of the issues. Indeed, he only appears to have done so because, like the good lawyer he is, he not only supplies the (empirical) answers, he also frames the questions in ways that all but dictate the answers. That is, he is successful in showing that the Court has not had a significant impact because he uses "significant" in a particular wayusually in terms of the hopes of activist lawyers whose declarations were often uttered in the heat of battle. By presenting these exaggerated expectations as "the" goal of the courts, he makes it relatively easy to expose the great gap between the goal and the reality of subsequent events, to show that the goal was not reached or that it was reached by roads other than those paved by the courts. This argument is aptly captured in the book's title-_"the hollow hope." In short, Rosenberg argues, the belief that the Court has effected significant social change is a "myth."

However, this way of formulating the problem raises the well-known "gap problem" in the sociology of law. And as all students of this problem know, such a formulation is highly problematic because the researcher him- or herself has great latitude in postulating the "goals" of the law, and thus research is constantly in danger of doing little more than revealing the gap between the law-in-action on one hand and the researcher's own views on the other. Rosenberg falls into this trap.

Rosenberg sets up his study to test two competing models of courtsa "constrained court" model, which argues the courts have limited powers, and a "dynamic court" model, which holds that the court is a significant independent force for change. The bulk of the book challenges the dynamic court view. The expectations of those holding it are culled from an ad hoc collection of proponents of judicial activism, and it is this view which he uses in each of the case studies as the backdrop against which he frames his analysis. Although Rosenberg wavers between using reformers' hopes and the Court's own rulings (the "law on the books") as the backdrop against which he contrasts actual consequences, the book's primary emphasis is on the gap between Rosenberg's formulation of reformers' aspirations on the one hand and the actual consequences of the courts' decisions on the other. Only to a much lesser extent is it about contrasting

7. Indeed, proponents of restraint at times appear to attribute even greater power to the federal courts than do those who embrace judicial activism. From Holmes to Frankfurter to Bickel to Bork, opponents of judicial activism have attributed enormous influence- or potential influence-to the Court. Their opposition to activism has been based not on the fact that the courts are not powerful but on the fact that the principles of democracy dictate deference to the other branches. 
court rulings with subsequent behavior. As students of the gap problem have long acknowledged, ${ }^{8}$ identifying the aims of the law is highly problematic; identifying the aims of reformers is likely to be even more so. By postulating them himself, and by not making them problematic, Rosenberg ignores what many would regard as the central task of sociolegal analysis. Whatever the case, his substitution of the hopes of an ad hoc collection of reformers for the "aims" of the law goes a long way toward facilitating his "findings" of inefficacy. By framing the questions in terms of the exaggerated rhetoric of reformers, he has all but dictated his findings in advance.

It is in this sense that I think him a better lawyer than social scientist. He purports to answer questions about the effects of law, but in fact he has subtly reframed issues around the gap between his version of reformers' aspirations-and not the Court's rulings-and subsequent behavior. In writing this way, he reveals more about reformers's exaggerations, or more precisely his own disillusionment with reformers' misplaced zeal, than about the courts. In this sense the book reveals as much about Rosenberg as it does about the Court.

I emphasize this distinction between Rosenberg's version of the hopes of the reformers and the Court's own hopes and rulings, because the data he marshals and the answers he provides, which at first blush appear to be so impressive, largely dissolve when viewed in light of the Court's rulings.

To appreciate this, we ask several questions. First, which reformers is he talking about? Why are they important? What makes their views significant? Then, we must look not only at the reformers' aspirations but the Court's own rulings-not only what it said but what its specific holdings were. 9 This is important because there may not be such a big gap between the rulings and their subsequent effects. Rather the gap may be between the reformers' aspirations and subsequent events.

Although he draws on many sources and quotes many of them at length, Rosenberg is not at all systematic in his effort to locate those reformers and other observers whose hopes he finds hollow. Perhaps he views it as unnecessary; after all, these views may be so commonly held that it is impossible to locate a school of proponents. But to say that he has not clearly identified this group does not mean that he has not identified anyone. By my rough count, he mentions 42 advocates of the "dynamic court" whose hopes he concludes are hollow. ${ }^{\text {to }}$ (The inclusion of

8. One might add to this list of concerns critical legal studies scholars who have made the "indeterminacy of the law" the centerpiece in their analysis of law.

9. Rosenberg's book purports to be about courts and social policy, but in fact is almost entirely about one court, the United States Supreme Court. For this reason, throughout this essay the court I refer to is almost always the U.S. Supreme Court.

10. He also treats from time to time another group who believe that court rulings have had significant social effects but deplore them. For instance, in Courts and Social Policy (cited 
several of these people might be challenged because he mentions them only in passing or only briefly quotes from them.) Of this list nearly half are activist lawyers and another quarter are judges and law professors. The rest are a smattering of political scientists, journalists, and others whose professions I cannot identify. But with respect to the frequency of citations and the length of quotes, the focus is overwhelmingly on activist lawyers and judges. In essence, he contrasts the wishes, desires, and hopes of these reformers with subsequent social policy developments related to important Supreme Court decisions.

So far as I can tell, this group of reformers is an ad hoc collection of activists (and their friends) who exaggerate claims about their own efficacy. That there is a huge gap between their views and subsequent policies is hardly surprising. Imagine such a study of sports teams, contrasting coaches' preseason thetoric with the teams' performances during the season ("This team has a legitimate shot at the championship; on a good day it can beat anyone"-yet the team finishes three games out of the cellar). Or imagine someone reporting that there is a huge gap between candidates' campaign pronouncements and policies after election. Would anyone complain that the coaches had hollow hopes or that the information about the candidates is newsworthy? I suspect that no one other than a few sports writers, or opposition candidates, would find it worthwhile to take such rhetoric seriously. Certainly no one would take it as a disinterested diagnosis of the strength of the team or the candidate.

Yet this is more or less what Rosenberg has done; he has taken the rhetoric of the intensely partisan at face value and then shown that performance falls short of rhetoric. What he does not do is offer any reason-convincing or not-why observations of this group should be taken so seriously. I emphasize this because his book is so relentless. Each case study follows a similar format: each begins with a mobilization of quotes by reformers which are then followed by a piling on of data to show that they were wrong. But Rosenberg never pauses to ask what the views of these reformers signify or why they are privileged voices to be taken so seriously.

I can, however, think of one group whose voices should be privileged and whose views should help shape the inquiry into the efficacy of litigation. This group is sociolegal scholars who have examined the role of courts in producing social change. There is a small group of scholars who have examined this issue, and Rosenberg is certainly aware of them and

in note 1), Horowitz argues that the courts have enormous impact on public policy but almost always in a destructive way. He argues that they have undermined the quality of teaching in public schools, the efficacy of rehabilitation for juveniles, the efficacy of criminal procedure, and the like. In short, his thesis is that when the courts attempt to make social policy, they make messes. But they do make something! In contrast, Rosenberg argues that the courts do not have any kind of effect. 
draws on them from time to time. But he hasn't really built on them, no doubt because their observations do not produce such dramatic copy, since most of them come to findings that are not all that dissimilar from his own. Indeed, one is hard pressed to find an empirically oriented sociolegal study making claims that are markedly different from his. The fact is that the conventional wisdom among political scientists and sociologists who have studied these matters is that the courts by themselves are not very powerful and, at best, are important at the margins or in conjunction with other governmental bodies. From this vantage point, Rosenberg's findings are themselves part of the conventional wisdom of sociolegal studies and appear to be news only because they are juxtaposed against exaggerated political rhetoric.

I do not mean to claim that Rosenberg's study is without merit. I think it is first rate because he examines the biggest of the big decisionsdesegregation, abortion, women's rights, criminal procedure--and because he insists on rigorously marshaling and examining evidence. Furthermore he attempts to specify more systematically than most others the constraints and conditions that limit the Court's ability to effect significant social policy. Finally, his conclusions are presented more clearly and boldly than those of others. But I do want to emphasize that his findings are not markedly different from those of other social scientists who work in this area. ${ }^{11}$ It is a sad truth that much social science is little more than showing conventional wisdom to be false. But the exaggerated claims of the intensely partisan make especially easy targets and an analysis of them does little to clarify issues and advance understanding.

Had Rosenberg chosen to build on the work of sociolegal scholars rather than flail at naive reformers (or at least the seemingly naive statements of reformers) and their friends and critics, his study would have been better. For instance, had he been interested in understanding their motivations and expectations, he would have done well to take the work of Michael McCann more seriously. In Taking Reform Seriously: Perspectives on Public Interest Liberalism, McCann explores the aims, tactics, and expectations of law reformers of the 1960s and 1970s and finds that they are not as naive as Rosenberg's ad hoc array of quotes makes them out to be. ${ }^{12}$

As well Rosenberg could have drawn more extensively on the work of Stuart Scheingold. In The Politics of Rights Scheingold also argues that courts have extremely limited ability to directly effect social change, and indeed Rosenberg's discussion of the courts' limitations closely parallels

11. See, e.g., Robert Dahl, "Decision-making in a Democracy: The Supreme Court as a National Policy Maker," 6 J. Pub. L. 279 (1957); Scheingold, The Politics of Rights (cited in note 1); David Adamany, "Law and Society: Legitimacy, Realigning Elections, and the Supreme Court," 1973 Wis. L. Rev. 791; and Jonathan Casper, "The Supreme Court and National Policy Making," 70 Am. Pol Sci. Rev. 50 (1976).

12. Ithaca, N.Y.: Cornell University Press, 1986. 
Scheingold's own discussion. But Scheingold goes on to develop the intriguing hypothesis that courts can facilitate the placement of issues on the public agenda and thus can serve as catalysts for significant social change. His argument rests on a belief in American exceptionalism vis-à-vis the importance of law and the rhetoric of rights. It is a subtle discussion of American concern with "rights," the centrality of law and litigation as a way of articulating these rights, and the symbolic importance of this language in the American political process. Rosenberg has obviously read Scheingold's work, ${ }^{13}$ and indeed he seeks to test the hypothesis that the Court is an important "indirect" agent for social change. But his somewhat perfunctory analysis does not do justice to Scheingold's rich discussion of the symbolic importance of the rhetoric of rights in American public life.

Rosenberg may be correct in asserting that courts are not even important in developing symbols, myths, and expectations and thus as catalysts for change, but he could have built more systematically on Scheingold's effort in examining this issue. Indeed, the very fact that so many people believe the courts are so important in effecting social change, despite Rosenberg's findings that they obviously are not, lends considerable plausibility to Scheingold's argument about the symbolic importance of the language of rights. It may be that Brown, Roe, and Miranda have become important symbols that serve to promote new national aspirations. An examination more subtle than Rosenberg's inquiry into the "indirect" effects would be required to explore this hypothesis.

\section{HOLLOW HOPES AND COURT ORDERS}

I have asserted that Rosenberg's analysis is problematic because it contrasts the gulf between the exaggerated expectations of a handful of reformers (and some of their critics) on one hand and subsequent behavior of those targeted by the Court on the other. In focusing on them, Rosenberg has not paid enough attention to the decisions of the Supreme Court itself. I emphasize this because the Court's rulings were much more modest than the hopes he attributes to the reformers. If efficacy is a function of the distance between reach and grasp, had he concentrated on the Court's rulings rather than the zealots' hopes in depicting the reach, he might have found the Court more efficacious than he did. In addition, he probably would have found precious few of the justices who expected their rulings to effect significant change in the absence of corresponding actions by other political units.

13. The entire structure of Rosenberg's book owes much more to Scheingold's book than Rosenberg probably realizes. 
Let me offer some examples. Rosenberg's measure of the efficacy of Brown v. Board of Education, the landmark school desegregation decision, is the percentage of black and white schoolchildren attending mixed-race schools, certainly a concern of many of those who supported school desegregation efforts. But a reading of Brown and its progeny even into the late 1960 s and 1970s doesn't reveal that "integration" was a central goal. If we have to find one word to capture the aspirations of these decisions, it would not be integration, but desegregation, the elimination of apartheid, official, state-sanctioned systems of racial separation. Despite the language that "separate" is inherently unequal, in the context "separate" meant legal segregation, not all forms or practice that might serve to divide students along racial or class lines. Even when upholding the most expansive of remedial orders, in the process of implementing Brown, the Supreme Court was careful to emphasize that its goal was to root out the residue of state-sanctioned systems of racial separation, not the independent promotion of racial integration.

Indeed, even here the Court was modest. For years after Broun, it did virtually nothing to give concrete meaning and urgency to Brown. It was not until the late 1960 s that it struck down miscegenation laws. Although the Court often invoked images of a racially integrated society, its concrete rulings focused almost entirely on eliminating official, state-sponsored segregation, and it used fixed figures for racial "balance," with but few exceptions, only in the context of overcoming such policies. Only occasionally did the Court on its own go beyond this and embrace a more aggressive idea of integration, as it did in Griggs. ${ }^{14}$ But even here when it did begin to experiment with a more expansive social agenda, it quickly retreated. Thus although many reformers who mobilized for Brown or who were encouraged by the decision no doubt saw it as a vehicle for an expansive social agenda, it is not clear that a majority of Justices themselves saw it this way. Certainly aggressive integration (as opposed to aggressive deseg-

14. Griggs v. Duke Power Co., 401 U.S. 424 (1971), invalidated an employer's use of educational criteria and general intelligence tests as conditions of employment and advancement when neither standard was shown to be significantly related to successful job performance; both requirements operated to disqualify blacks at a significantly higher rate than whites; and the jobs in question had traditionally been held by whites as part of a long-standing practice of discrimination against blacks. In deciding this case, the Court emphasized that it was basing its decision on the Civil Rights Act of 1964 and that it was invalidating the use of these tests in a company that had a history of racial discrimination. Thus, even here, in one of the Court's high watermarks for the "effects" test (as opposed to the more conservative "intent" test), the Court stressed the pattern of discrimination in the company involved in the suit (as opposed to the general social goal of an integrated workforce) and that it was deciding the case under statutory, not constitutional, principles. In short, the Court may have been "constrained" by other more powerful political branches, but the constraint appears to be self-imposed. Here, too, the Court's "reach" is far more modest than that implied by Rosenberg, and the gap between its reach and actual grasp is far less than he implies. It was not simply slapped down by more powerful political forces; it simply did not try to do too much. 
regation) is not a stated policy preference in Brown, Green, Swann, ${ }^{15}$ or any of the other landmark Supreme Court decisions. Obviously many people embraced a broader aspiration for school desegregation other than the formal end to a policy of apartheid, and a broader policy was eventually embraced in legislation and within the departments of Justice and Education. But perhaps for many of the reasons put forth by Rosenberg, the Court itself did not articulate any such broad vision, and contented itself with rulings of relatively modest scope. ${ }^{16}$

I do not dispute that many people hoped that Broum and its progeny would lead to-or in fact was-the vehicle for a much more aggressive effort. But it is a misreading of Brown and even the later more expansive rulings to assert that racial integration was a-or the-goal of the Court in Brown. Such a reading highlights a dramatic gap between reach and grasp. But it is not clear whose reach is being measured and, hence, what "gap" is being discussed. If I am correct, the Court's reach was much more modest, and correspondingly the gap Rosenberg finds is far smaller and perhaps the effects are greater.

Let me illustrate my concern by examining still another decision Rosenberg claims was almost wholly inefficacious, Miranda v. Arizona. Here, too, his treatment of doctrine is strange. Leading off with warnings by Justice Harlan in dissent, he cites a number of critics who have complained that the decision did or could have handcuffed the police by allowing obviously guilty criminals to go free. And he cites still others who expected the decision to revolutionize relations between suspects and the police. He then goes on to show that these various expectations have not come to pass. Indeed, he reports (pp. 324-28, 329) that "the evidence strongly suggests that the confession rate did not change because the Miranda warnings were unable to alter [the imbalance] between interrogators and suspects." By thus framing the question, he assumes that the purpose of

15. Brown v. Board of Education, 347 U.S. 483; Green v. County School Board of New Kent County, 391 U.S. 430 (1968); Swann v. Charlotte-Mecklenburg School District, 402 U.S. 1 (1971). In Green, the Court reiterated that Broun's purpose was to eliminate the vestiges of "state-imposed segregation" (my emphasis) and thus struck down a seemingly neutral "freedom-of-choice" plan because it perpetuated the official segregation policy that had preceded it. In Swann, the Court affirmed a district court's powers to act decisively to fashion plans to desegregate schools in the face of continued school board resistance. But in doing so, it emphasized that these actions were "remedial," that they were efforts to eliminate all vestiges of state-imposed segregation in order to convert officially desegregated dual school systems into unitary systems. Here, too, the Court stressed its power to eliminate the vestiges of state-sanctioned, official discrimination rather than any affirmative vision of an integrated society.

16. Admittedly the declaration of the death of apartheid was in itself bold and dramatic. In one fell swoop, nine old men made a decision that had the potential for significantly affecting the lives of many millions of people-most of whom were concentrated in a region of the country whose citizens still within the memory of some had initiated a bitter civil war over related matters. And admittedly at some point vigorous efforts to desegregate (i.e., end apartheid) meld into efforts to integrate. Loving v. Virginia, 388 U.S. 1 (1967). 
Miranda was to alter in significant ways relations between police and suspects.

But there is no compelling reason to read Miranda this way. It makes more sense to read it as an effort to devise a practical rule for dealing with challenges to confessions and self-incriminating statements, one that gave some modicum of protection to the accused and subjected the police to some constraints, but nevertheless still facilitated use of incriminating statements made in police custody. In the years preceding Miranda the courts had become more aggressive in reviewing allegations of coerced confessions and had developed tighter rules governing the use of evidence. Thus the courts were faced with the possibility that they would have to decide issues of admissibility case by case-a jurisprudence of fact-that would have been an administrative nightmare. A clear rule, especially one that allowed for formulaic compliance, provided a solution to this dilemma. It had the virtue of clarity, underscored an appreciation for suspects' rights, and provided guidance for the police, even as it continued to permit reliance on evidence obtained through questioning. The Court's solution was to require the police to issue a warning before questioning but couple it with the option of informed consent and waiver. So, far from being a decision to undermine use of confessions, Miranda can be read as a decision to protect the legitimacy of confessions. Or at least it can be seen as a way of curbing police use of third-degree tactics by placing some roadblocks to questioning in their way without having to abolish altogether the long-standing practice of questioning suspects. Whatever the case, it strains credibility, and certainly the text of the decision, to view Miranda as a decision whose purpose was to reduce substantially police reliance on evidence supplied by suspects themselves. ${ }^{17}$

In short, the Court in Miranda did what all sorts of professionalslawyers, doctors, professors-have come to rely on: extend rights to a vulnerable group with one hand but then facilitate informed consent and waiver on the other. We may not like ritualized warnings and waivers, but such practices are standard fare in all walks of life in modern society. Doctors routinely use them when dealing with patients, college professors when writing letters of recommendation, and so on. Not to rely on routine warnings and waivers would require that we repeatedly engage in searching inquiries in individual cases. But this is precisely what the Court may have been seeking to avoid in Miranda.

Let us briefly examine another of Rosenberg's case studies, that of reapportionment. Rosenberg quotes several observers at length, showing

17. Had this been the Court's intention, one would have expected it to have been more aggressive in expanding right to counsel to suspects at the earliest stages in the criminal process or developed something like a "duty" of silence until consultation with a lawyer. Although some police departments experimented with placing lawyers in the station houses, the Court never encouraged this and certainly did not mandate it. 
that a number of them regarded reapportionment as an instrument for revitalizing central cities. Once court-ordered reapportionment was effected, they hoped, urban centers would receive a greater share of the representation and a larger share of public resources. Here, too, Rosenberg's big news is that this did not occur. The big winners were the suburbs, which it turned out had more in common with rural areas, which had been vastly overrepresented prior to reapportionment, than with the central cities. However, as widespread as these sentiments for urban revitalization were and as attractive as they seemed at the time, such expectations are not found in the text of any of the Court's major apportionment decisions. Instead, the Court emphasized procedural issues in these decisions-the belief that in a fair system of political representation each vote should count more or less equally. However much the Justices may have had a political agenda when ruling on reapportionment, and however much they were biased in favor of one theory of representation over others, by and large they appear to have been following an intuitive sense of fairness without significant regard to consequences.

No doubt Rosenberg is correct in believing that many saw reapportionment as a means for empowering the central cities and neglected to consider the priorities of the fast-rising suburbs, seniority systems in legislatures, implications for racial gerrymandering, and the implications of all these for reapportionment and urban interests. But there is no real news in this. What all this tells us is that there was a handful of observers who were wildly optimistic with respect to the impact of the Supreme Court's reapportionment decisions. Here too, the gap implied in the book's title, The Hollow Hope, is not so much the gulf between the Court's rulings and what happened later, but the gulf between the great expectations of a handful of ill-defined enthusiasts of reapportionment and what happened later.

In each of these case studies-and others not mentioned here-Rosenberg concludes that the Court was weak because the goals of the reformers were not met. But as I have tried to show, the Court never even attempted to do what he observes it did not do. It is hard to know what to make of such observations. At best it is myth debunking, although if so, we need to know more about the myth than he tells us. He promises to explicate this myth with his second provocative metaphor, "flypaper." But, as we shall see, he does not keep the promise.

\section{FLYPAPER}

Who is attracted to the Court and why? A substantial number of people attribute exaggerated powers to the courts. It would be interesting to know who they are. Unfortunately Rosenberg does not explore this 
group systematically. At the outset of each case study he marshals quotes from a variety of sources revealing that a number of prominent people have had great expectations from litigation. But he provides no sustained discussion as to how he selected those to be quoted, or who they are-why their views matter. One way to summarize his argument is as follows: "A lot of people think the Court is really powerful, but my study reveals that it isn't." Even if he is correct, and I am impressed with the data he has marshaled, his study is at most a successful effort at debunking an ill-defined myth than it is in explaining the nature of the Court's powers or the pervasiveness and significance of the myth.

A more sociological and theoretically informed study would have used the myth-the "hollow hope"-as the beginning of inquiry rather than the conclusion. It would have gone beyond myth debunking and asked, Who holds this "hollow hope"? Why do they persist in holding a belief that is so patently false? What functions does the myth serve? What is the nature of the flypaper Court? What functions does it serve? Throughout the book, Rosenberg raises such questions, but he never addresses them.

Indeed, his brief concluding chapter, "The Fly Paper Court," is a disappointment. The metaphor promises to explore the seductions of the Court and those attracted to it. Yet it only reiterates his point that those who place their faith in the Court as an engine of social change are misguided. This, of course, is an important point, but the question is, Why are so many people then attracted to the Court? We know why flies are attracted to flypaper; flypaper is aromatic and flies are dumb. But the people Rosenberg identifies who are attracted to litigation are not so dumb; they are prominent lawyers, journalists, and public officials. How can they be so misguided?

One can also ask, Is the metaphor apt? Certainly the metaphor is powerful: The Court attracts would-be reformers only to entrap them in a futile struggle. But flypaper is designed for this purpose. Is the Court? Is the Court responsible for trapping would-be reformers? Or has someone else fostered the myth? And is it in fact as dysfunctional as Rosenberg argues?

Whatever the case, the anomaly Rosenberg has identified-the deep belief in a powerful Court coupled with a finding of abject weaknessshould have been a central problematic in the study. To conclude that the Court is like flypaper that entangles would-be reformers in a fruitless enterprise is to pose a problem, not conclude the analysis. Thus the unasked and unanswered questions: Who fosters the myth of the dynamic court? Who maintains it? What social functions does it serve? Rosenberg's book would have been far more satisfying had he pursed such questions.

Let me outline two somewhat divergent directions such an inquiry might take. I have already suggested one of them. The rulings of the 
courts were much more modest than the quotes of the handful of reformers suggest, and hence the gap between aspiration (of the Court), and impact less dramatic. The result is that the courts may relative to their aspirations look more efficacious than Rosenberg has portrayed them. If one added to this reformation of the "gap" an analysis of the strengths and limits of other branches of government (something that Rosenberg fails to do), the courts might look even more impressive.

No doubt Rosenberg would reject a resolution of the anomaly he has portrayed by means of downward revision of the reformers' or the Court's expectations. Indeed, I suspect he would claim that his mobilization and presentation of the (exaggerated) aspirations of the reformers is a major strength of the book. No doubt he would defend his extensive quoting of reformers on the grounds that they are representative, that they reveal conventional wisdom among (at least liberal) national opinion makers. To resolve the puzzle by deflating the claims would not do for him.

Assuming that he in fact is right, that conventional wisdom accords vast but unwarranted powers to the federal courts, how else might one attempt to account for the paradox? Let me suggest another tack and offer some evidence for its support: the myth is functional for the legal profession, particularly the elite of the profession-professors at leading law schools, federal judges, bar association leaders, partners in major firms, and the like. By promoting the belief in an extraordinarily powerful court, they enhance their own status. By fostering the myth of extraordinarily powerful judges, they imply extraordinarily powerful lawyers, law professors, and law students.

This belief of the powerful agent of good is also part of the quintessential American myth, the power of the Lone Ranger who emerges from nowhere to challenge injustice. Although correcting injustice through public interest litigation is not quite as simple and neat as the Lone Ranger's solution, it may be the late 20th-century equivalent. Consider some of the representative works in the genre, Anthony Lewis's Gideon's Trumpet, Gerald Stern's Buffalo Creek Disaster, and Jack Peltason's FiftyEight Lonely Men, to say nothing of the dozens of popular movies and television programs. The list could obviously be extended. A common theme in such stories in this genre is that a single brave person or small group of people battles evil powers against great odds to achieve great things. Litigation has replaced the gun; the lawyer, the Lone Ranger; and the courtroom, Main Street as the scene of the confrontation. But the structure of the drama remains.

Note that an exaggerated sense of power need not be held only by those embracing a dynamic court view. Their critics, advocates of restraint, can hold it as well. Indeed, Justice Frankfurter may be the quintessential proponent of the myth, his appeal being all the more powerful 
because it rests on a depiction of the Court as an especially awesome and powerful force. At times his appeal for restraint is almost theological: Lawyers and judges in their infinite wisdom probably can devise good solutions to solve social problems, but (for God) to intervene might undermine the free will of humankind. So it is the task of the high priest, in the name of the awesome power, to urge self-restraint. Humankind is allowed to engage in folly if it wishes; that is the price that must be paid for political maturity. Thus even the most powerful counsel to embrace judicial restraint is framed in such a way as to assume awesome powers of the Court.

By contrast, Rosenberg seems to be saying, Whatever the courts do, they simply are not very important. His findings make ponderous discussions about the awesome responsibility of federal courts appear ridiculous, indeed comical, and the claims of effecting significant social change foolish. Rosenberg unwittingly presents us with material for a Monty Pythonlike skit which irreverently exposes pomposity. Imagine, for example, such ponderous discussion when exploring the roles and responsibilities of alderpeople in Cleveland, sewage district supervisors in Contra Costa County, state legislators in Oklahoma, and the like. But this is roughly the league in which Rosenberg wants to place the federal courts. People may expect them to provide the moon, but according to him they cannot even turn on a street light.

But the difference between the myriad nameless local public officials and the Supreme Court is that the latter is a small and visible group which has the legal profession to promote it. And by promoting it, the profession promotes itself. By exaggerating the efficacy of the institutions in which they work or about which they teach and write, lawyers enhance their own status and prestige.

However, one need not be so cynical. The exaggerated belief in the importance of the federal courts may be an example of misplaced noblesse oblige; the profession may have assumed the traditional belief of the upper class, that they have a distinctive responsibility for shaping moral sensibilities and maintaining public institutions. ${ }^{18}$

In this vein John Brigham has written an excellent book, The Cult of the Court, ${ }^{19}$ whose title nicely illuminates his central thesis. In it Brigham explores what he regards as the near fetish-like interest in the Supreme Court and tries to link this concern with broader currents in American politics. This literature and Brigham's book in particular should have been drawn on had Rosenberg been interested in trying to resolve the paradox he so convincingly presents. Whatever the case, Brigham's book

18. This was one of Tocqueville's striking observations in Democracy in America (Garden City, N.Y.: Doubleday/Anchor, 1969). The expansion of the power and prestige of lawyers since its publication in 1836 only underscores his argument.

19. John Brigham, The Cult of the Court (Philadelphia: Temple University Press, 1987). 
certainly helps make sense of what Rosenberg unknowingly reveals as a puzzling and unresolved paradox. Neither Brigham nor I of course is the first to discover legal fetishism; there is a small industry that has dissected the self-puffery of the legal profession and exaggerated sense of importance of the law. ${ }^{20}$

Nor in fact do I believe that an explanation along these lines can dispose of the issues-in large part because I subscribe to the belief that if Rosenberg had lowered his expectations, he would have concluded that the power of the courts relative to other governmental agents is not insubstantial.

As I said at the outset I think that Rosenberg is a better lawyer than political scientist. Although he is reacting vigorously to the myth he so convincingly reveals, nevertheless he, too, has been captured by it. $\mathrm{He}$ treats it more seriously than perhaps is warranted. As a social critic, he fails to exploit the obvious absurdity in the great gap between great hopes and puny consequences, and as a social scientist he fails to explore the social functions of the widespread belief in the efficacy of the courts. But he has laid out an important problem. We await the sequel, which might be entitled The Functions of the Hollow Hope.

20. See, e.g., Kristen Bumiller, The Civil Rights Society (Baltimore: Johns Hopkins University Press, 1990); Richard Abel, "Why Does the ABA Promulgate Ethical Rules?" 59 Tex. L. Rev. 639 (1981). 